\title{
STAKEHOLDERS' CONTRIBUTION IN THE PROVISION OF EARLY CHILDHOOD EDUCTION IN BOTSWANA: SUCCESSES AND OBSTACLES
}

\author{
N. B. Mswela ${ }^{\mathrm{i}}$ \\ Faculty of Education, \\ Department of Primary Education, \\ University of Botswana, \\ Botswana
}

\begin{abstract}
:
This desktop study sought to consider the roles and responsibilities of various stakeholders in the provision of ECE in Botswana. The article is a document analysis study and starts by defining ECE and the importance of ECE in policies used in Botswana. It further presents the roles and responsibilities of various stakeholders in the provision of ECE services as well as ideas to improve ECE provision in Botswana.
\end{abstract}

Keywords: early childhood education, policies, stakeholders, standards

\section{Introduction}

According to the National Policy on Education (2004), Early Childhood Education is the education given in an educational institution to children prior to their primary school entry. The early years of childhood are crucial in the development of an individual. They are foundational to the success or failure of the whole system of education. Any support given at this stage helps promote young children's development. Early Childhood Education refers to branches of education and care of young children from birth to 8 years (Meier \& Marais, 2012) often referred to as pre-schools, kindergartens, nurseries or crèches.

Early Childhood Education is an integral part of modern education systems in many countries and the Botswana government has acknowledged this need. In Botswana ownership of ECE has predominantly been within the context of private institutions and individuals. However, the Government of Botswana has now made an important commitment in this regard.

Various policies are used in the provision of ECE in Botswana. These policies have been aligned with global interest such as the 1990 Jomtein Conference Education for All held in Thailand, the most prominent being: The Revised National Policy on Education

${ }^{i}$ Correspondence: email mswelan@mopipi.ub.bw 
of 1994 and Early Childhood Care and Education Policy of 2001. Although these policies have assisted stakeholders in Botswana in the provision of ECE services, they seem inadequate for assuring the quality ECE standards required.

As may be expected, increased interest in, and importance of ECE, comes with public investments directed especially at improving the development of all young children (Siraj, 2015; Icenberg \& Jalongo, 2010; Demma, 2010 and Aguilar \& Tansini, 2011). A number of benefits are cited for having quality Early Childhood Education. These include, but are not limited to: positive effects on young children's cognitive, social, and emotional development (Gordon \& Browne, 2017; Cohen \& Best, 2013 and Ishimine \& Tayler, 2014).

\section{ECE stakeholders in Botswana}

Although various stakeholders have been tasked with the responsibility of the provision of ECE in Botswana, they are facing considerable obstacles regarding the facilitation of ECE. The following section presents the various stakeholders as well as their responsibilities and limitations in carrying out the mandate of coordinating ECE.

\subsection{Ministry of Education}

The role of the Ministry of Education (MoE) is to provide an enabling environment and make sure that the coordination of the ECE services is carried out efficiently by various stakeholders such as those in the private, not-for-profit and public sectors. This notwithstanding, the MoE, through its smaller unit called the Pre-school Division, still faces challenges in the management, supervision and general coordination of ECE services. This stems in part, from the fact that there is dual partnership between MoE and the Ministry of Local Government (MLG), and also because of financial challenges of the MoE (Botswana National Early Childhood Integrated Early Childhood Development Baseline Study, 2006). While the MoE sets the guidelines for running a centre, the MLG, through the Social and Community Development Department (Local Councils) register, inspect and supervise day care centres and nursery programs. What contributes to the difficulty is the fact that some centres do not allow the local councils to inspect them. Some of these centres self-evaluate and consider their programs to be outstanding and do not see any need for council inspection. Others refuse council inspection possibly because they underperform and fear that their licence to operate maybe suspended or rescinded.

\subsection{Ministry of Local Government}

The Department of Social Services has been mandated under the Ministry of Local Government with the responsibility of social welfare, safety and social protection of young children. The role of this Department is crucial in the education and development of young children. One of its duties is to ensure that the needs of orphaned and vulnerable young children are met. According to Botswana National Integrated Early Childhood Development Baseline Study of 2006, p. 35, the major role of the Department 
of Social Services is: "To develop, coordinate, facilitate, monitor, supervise and evaluate the implementation of social services programs throughout the country with a view to promoting social functioning of the individuals, groups and communities in order to improve the quality of life."

The Department of Home Economics at the University of Botswana has been tasked with the role of empowering families, especially women and young girls, and the coordination of ECE including supervision and monitoring of services. Currently, there is no system in place for parental education within the Department of Home Economics (Botswana National Early Childhood Integrated Early Childhood Development Baseline Study, 2006).

\subsection{Ministry of Health}

The role of the Division of Child Health under the auspices of the Ministry of Health focuses on the needs of a child such as health, immunisation and management of childhood illnesses. This follows the universal Millennium Development Goals, developed in 2000 following the adoption of the United Nations Millennium Declaration. All member states subscribed to these goals (Botswana National Early Childhood Integrated Early Childhood Development Baseline Study, 2006). The goals are poverty eradication, education for all, empowering women and promoting equality, under 5years mortality rate, maternal mortality, curbing HIV/AIDS and malaria, and ensuring environmental sustainability. It was therefore imperative for Botswana to ensure that it had mechanisms in place to reduce the under 5 years child mortality rate, hence the birth of The Division of Child Health.

The Division of Child Health was mandated with assessing birth defects and developmental concerns that might affect education and care of young children. According to the Botswana National Integrated Early Childhood Development Baseline study of 2006, this Division seemed to have a strong health care system with $99 \%$ children being immunised, and $85 \%$ of the population with access to health services within a 5-10 $\mathrm{km}$ radius (Botswana National Early Childhood Integrated Early Childhood Development Baseline Study, 2006).

\subsection{Ministry of Labour and Home Affairs}

The Women's Affairs Department within the Ministry of Labour and Home Affairs has been mandated with guiding the implementation of various gender development activities. In order to adhere to the Universal Declaration on Human Rights, Botswana has implemented a National Gender Program Framework (NGPF) which seeks to address gender inequalities and deal with issues of poverty, power decision making, education and training, health and HIV/AIDS. These issues affect ECE children worldwide including those in Botswana, some of whom on a daily basis, go to school hungry, abused, ill and traumatised (Icenburg \& Jalongo, 2010).

The Ministry of Labour and Home Affairs has a great deal of responsibility on its hands as Botswana is facing problems due to increasing numbers of orphaned and 
vulnerable children within the ECE programs who are particularly vulnerable because they are experiencing difficulties at a critical stage of their development. Intervention from stakeholders is needed to assist the optimal development of young vulnerable children.

\subsection{Parents}

The role of parents still remains a crucial factor in the education and care of young children. First and foremost parents are the most influential stakeholders in the education of young children (Meier \& Marais, 2012). Children's development of the cognitive and social skills needed for later success in school is supported by responsive parenting. Responsiveness plays an important role in providing a strong foundation for children to develop optimally. This includes positive affection and high levels of warmth, in combination with behaviors that are cognitively responsive to the child's needs (Hearron \& Hildebrand, 2015).

In Botswana, the majority of children grow up in environments that lack the responsive parenting needed for optimal development. Consequently, ECE programs in Botswana are now faced with a mammoth task of providing care, education and responsive parenting in one way or another. Teachers in ECE need not only training to teach young children but also training to exhibit positive affection, warmth, responsiveness and empathy for optimal development of children. Young children need environments that have positive interaction, warmth, care and education to enable their positive self-esteem and sense of intrinsic self-value (Hearron \& Hildebrand, 2015). It is therefore imperative that the training of ECE teachers should not only focus on care and education but also include issues such as teacher - pupil interaction, the building of selfesteem in young children, and empowerment of intrinsic self-value, which may be missing from their home backgrounds.

The involvement and participation of parents in the education of their young children is particularly crucial because it is through parental links that educators can narrow the gap between home and school. Such links are necessary because they create a platform whereby pertinent issues such as curriculum, fund raising activities, building of strong relationships and partnerships with families and parental education can all be discussed (Follari, 2015). Parents could be encouraged to assist with issues such as homework and personal hygiene of their young children.

The proverb that says 'it takes a village to educate a child' is highly applicable in the Botswana context, especially in ECE. The wider involvement will assist not only the teachers but also the children, as what is learnt in school will be enhanced at home in a contextual manner. Learning in a vacuum, that is, the acquisition of knowledge and skills without context is not effective for young children. Young children need to learn in context, and the inclusion of their parents could help make this possible (Follari, 2015). When such partnerships are created, children may receive the best from both the school and home. As suggested by Bronfenbrenner in (Hearron \& Hildebrand, 2015) the child's environment affects how a child grows and develops. 


\subsection{Teachers}

In a paper entitled Encouraging Quality in Early Childhood Education and Care by Organization for Economic Cooperation and Development (OECD), the authors point out that it is important for education systems to invest in rigorous teacher education and training if teachers are to deliver high quality outcomes. Despite knowledge of this, there is often reluctance by governments to raise staff qualifications as this may impact on wage demands (OECD, 2015). This present article suggests that not only should the Government of Botswana aim to hire quality teachers but also the private owners of ECE programs should do the same. Hiring staff that do not have the right qualifications is costly in the long term as it can impact negatively on the quality of education received by young learners.

OECD (2015) points out that although teachers are expected to have specific knowledge, skills and competencies, they are however, not provided with sufficient education and training to acquire those skills and competencies. The authors argue that well trained teachers are the key to provision of high quality ECE that can produce most favourable cognitive and social outcomes (OECD, 2015). In addition, Litjens \& Taguma (2010) state that enriched stimulating environments and high-quality pedagogy are fostered by better qualified staff; and better quality pedagogy leads to better learning outcomes. The point to emphasize is that the qualifications, education and training of ECE staff are an important matter in the education of young children.

The outcome of teacher training leads to efficiently trained teachers who are able to produce desired outcomes with regards to the teaching of young children. Essentially, it is important to have a solid teacher training program commonly referred to as preservice. This training program would be for all teachers in ECE and once those teachers are employed, it would be necessary for them to regularly update through in-service training. This may equip teachers with current trends, skills, and contemporary pedagogy and issues in ECE which may not have been necessary or even available when they were trained (Hearron \& Hildebrand, 2015). OECD (2015), p.2 states that while it is important to have qualified teachers, it must be noted however that "it is not the qualification of teachers per se that has an impact on child learning outcomes, but the ability of better qualified staff to create a high quality pedagogic environment that makes the difference".

The same authors state that key elements of staff quality include the way the staff involves the children by making stimulating interactions with and between children as well as using scaffolding strategies of guiding, modelling and questioning (OECD, 2015). In short, well trained staff can foster healthy and educative interactions that can lead to better self-esteem and self-concept development. This can boost a child's ego and perseverance to richer and higher levels of learning. It therefore becomes crucial that ECE teachers are adequately trained. 


\subsection{Trained leadership/management}

Hearron \& Hildebrand (2015, p.347) define leadership as a "process of social influence in which one person can enlist the aid and support of others in the accomplishment of a common task". The authors argue that being a leader in an ECE program is challenging and needs someone who can plan, organize and also delegate. Along with these qualities, the ECE leader must also be intelligent, visionary, have initiative, maturity, be decisive and have self-assurance (Hearron \& Hildebrand, 2015).

Leadership is an important aspect in an ECE program because it is through good leadership that a spirit of working together can be developed. Leadership in ECE involves sharing of ideas and establishing warm cordial relationships with the parents, children, teachers and other stakeholders. In many cases, in various organizations where a leader is not capable and does not possess the skills outlined above, there may be hostility, lack of cooperation, consultation and team sprit or togetherness. This may render the organization, (in this case an ECE program) dysfunctional thus leading to poor quality service. Good leadership is thus an important aspect of an ECE program. In short, the combined efforts of stakeholders mentioned above, can go a long way towards helping young children develop their full potential.

\section{Recommendations}

It is necessary to upgrade the current ECE teacher entry level to degree level for people seeking employment in the ECE field. They should also have studied Child Development as a course component because it will expose them to developmental issues of young learners that that relate to the education of young children (Henniger, 2017). Being equipped with knowledge of Child Development is necessary because the ECE professional will be able to assess a child's developmental needs, strengths, deficiencies and goals and thereby inform parents and others how to work with young children to accomplish their individual needs and interests.

The Head of the ECE program should be someone who has a Master's Degree in ECE or equivalent. This person will have extensive knowledge of ECE and be able to evaluate teachers in order to monitor and support their performance.

It would also be necessary for all stakeholders to work together rather than individually to improve the education of young children. Our young children are our future; therefore, all stakeholders need strong partnerships to advance this huge mandate of providing young children with the quality education they deserve.

\section{Conflict of Interest Statement}

The authors declare no conflicts of interests.

\section{About the Author}

The author of the article is a lecturer at the University of Botswana specialising in the teaching of Early Childhood Education for Bachelor of Education and Maters in Education students, in the Faculty of Education in the Department of Primary Education. 
She holds a PhD in Early Childhood Education, University of Botswana. Master in Education, University of Newcastle upon Tyne. Advanced Diploma in Child Development and Pre- School / Primary Education. Institute of Education. University of London. Bachelor of Education, Primary Education), University of Botswana. Her research interest is as follows: Quality in ECE and Accreditation as a quality measure. Her contact numbers are 74206626 and office number 3552249. She recites in Mochudi, a village $40 \mathrm{~km}$ from the capital city of Botswana, Gaborone.

\section{References}

Botswana National Early Childhood Integrated Early Childhood Development Baseline Study (2006). United Nations Children's Fund. Gaborone.

Cohen, C. \& Best, J. (2013). Early Care and Education; Policy Considerations for Ensuring High Quality Pre- K. Programs. Research for Education and Learning. Denver Publishers London.

Demma, P. (2010). Building Ready States. A Governors Guide to Supporting a Comprehensive, High, Quality Early Childhood State System. NGA Centre for Best Practices. Education Division.

Early Childhood Education \& Care Policy (2001). Division of Pre-School, Department of Education, Gaborone.

Follari, L. (2015). Foundations and Best Practices in Early Childhood Education: History, Theories and Approaches to Learning. Pearson, Boston.

Gordon, A. M, \& Browne, K. W. (2017). Beginnings \& Beyond: Delmar Learning. Australia. Hearron, P. F., \& Hildebrand, V. (2015). Management of Child Development Centres. New Jersey: Pearson.

Henniger, M. L., (2017). An Introduction to Teaching Young Children. Pearson Education. New Jersey.

Icenburg, J. P., \& Jalongo, M. R. (Eds). (2010). Major Trends and Issues in Early Childhood Education: Challenges, Controversies and Insights_Teachers College. New York. In Education. Sheffield; University of Sheffield Division of Education.

Ishimine, K., \& Tayler, C. (2014). Assessing Quality in Early Childhood Education and Care European Journal of Education. Vol 49 (2) 272-290.

Jomtiem World Conference for All. (1990). World Reports. Thailand.

Litjens, I., \& Taguma, M. (2010). Leadership, Quality and Professionalism. Early Childhood Education and Care, Vol2010/3. OECD. Paris.

Meier, C., \& Marais P. (2012). Education Management in Early Childhood Development, 2nd Edition, Open University Press. London.

Organization for Economic Cooperation and Development (OECD) (2015). Encouraging Quality in Early Childhood Education. Qualifications, Education and Professional Development. OECD. Paris. 
N. B. Mswela

STAKEHOLDERS' CONTRIBUTION IN THE PROVISION OF

EARLY CHILDHOOD EDUCTION IN BOTSWANA: SUCCESSES AND OBSTACLES

Siraj, I. (2015). Effective Practice in Early Years: Long Term Impact in Maths and English to End of Primary School and Beyond. A Paper Presented at the Public Lecture at the University of Botswana.

articles agreeing that a Creative Commons Attribution 4.0 International License (CC BY 4.0) terms will be applied to their work. Under the terms of this license, no permission is required from the author(s) or publisher for members of the community to copy, distribute, transmit or adapt the article content, providing a proper, prominent and unambiguous attribution to the authors in a manner that makes clear that the materials are being reused under permission of a Creative Commons License. Views, opinions and conclusions expressed in this research article are views, opinions and conclusions of the author(s). Open Access Publishing Group and European Journal of Education Studies shall not be responsible or answerable for any loss, damage or liability caused in relation to/arising out of conflicts of interest, copyright violations and inappropriate or inaccurate use of any kind content related or integrated into the research work. All the published works are meeting the Open Access Publishing requirements and can be freely accessed, shared, modified, distributed and used in educational, commercial and non-commercial purposes under a Creative Commons Attribution 4.0 International License (CC BY 4.0). 